\title{
PENGETAHUAN PERAWAT TERKAIT ISSU KESELAMATAN PASIEN
}

\section{Dwi Syafriningsih}

\section{Email : dwisyafriningsih@gmail.com}

\section{LATAR BELAKANG}

Keselamatan pasien di Indonesia mengacu pada beberapa regulasi seperti UndangUndang Rumah Sakit Nomor 44 Tahun 2009 pasal 43 yang menyebutkan bahwa rumah sakit wajib menerapkan standar keselamatan pasien dan Peraturan Menteri Kesehatan Republik Indonesia Nomor 11 tahun 2017 yang menyatakan setiap fasilitas pelayanan kesehatan harus menyelenggarakan keselamatan pasien.

keselamatan pasien yaitu menurut Emanuel (2008), yang menyatakan bahwa keselamatan pasien adalah disiplin ilmu di sektor perawatan kesehatan yang menerapkan metode ilmu keselamatan menuju tujuan mencapai sistem penyampaian layanan kesehatan yang dapat dipercaya. Keselamatan pasien juga merupakan atribut sistem perawatan kesehatan; Ini meminimalkan kejadian dan dampak, dan memaksimalkan pemulihan dari efek samping.
Keselamatan pasien terutama berkaitan dengan penghindaran, pencegahan dan perbaikan hasil buruk atau injuri yang berasal dari perawatan kesehatan itu sendiri. Ini harus membahas kejadian yang mencakup rangkaian "kesalahan" dan "penyimpangan" terhadap kecelakaan.

Keselamatan pasien terkait dengan "kualitas perawatan", namun kedua konsep tersebut tidak identik. Keselamatan merupakan bagian penting dari kualitas. Sampai saat ini, kegiatan untuk mengelola kualitas tidak terfokus secukupnya pada masalah keselamatan pasien (National Patient Safety Foundation, 2000, dalam Vincent, 2010).

Keselamatan pasien dan kualitas pasien adalah jantung dari penyampaian layanan kesehatan. Untuk setiap pasien, yang merawat, anggota keluarga dan profesional kesehatan, keselamatan sangat penting untuk penegakan diagnosa, tindakan kesehatan dan perawatan. Dokter, perawat dan semua orang yang bekerja di sistem kesehatan berkomitmen untuk merawat, membantu, 
menghibur dan merawat pasien dan memiliki keunggulan dalam penyediaan layanan kesehatan untuk semua orang yang membutuhkannya. Telah ada investigasi yang signifikan dalam beberapa tahun terakhir dalam peningkatan layanan, peningkatan kapasitas sistem, perekrutan profesional yang sangat terlatih dan penyediaan teknologi dan perawatan baru. Namun sistem kesehatan di seluruh dunia, menghadapi tantangan dalam menangani praktik yang tidak aman, profesional layanan kesehatan yang tidak kompeten, tata pemerintahan yang buruk dalam pemberian layanan kesehatan, kesalahan dalam diagnosis dan perawatan dan ketidakpatuhan terhadap standar (Commission on Patient Safety \& Quality Assurance, 2008).

\section{METODE}

Metode dalam penulisan ini menggunakan metode kualitatif, yaitu merupakan metode yang sifatnya memberikan suatu penjelasan dengan analisis. Metode ini bersifat subjektif, yaitu proses penelitian yang lebih fokus pada landasan teori.

Metode yang digunakan dalam kajian ini adalah Literature review. Metode ini menganalisis, eksplorasi dan kajian bebas pada artikel, jurnal, maupun e-book yang releven dan berfokus pada metode pembelajaran klinik yang mempengaruhi pengetahuan mahasiswa mengenai issu terkait dengan keselamatan pasien. Adapun artikel yang digunakan pada literature review ini adalah artikel yang didapatkan dengan memuat 3 database Pubmed, Geogle Scholar dan Science Direct.

\section{HASIL}

Menurut hasil dari beberapa pencarian literature didapatkan hasil Insiden keselamatan pasien yang merugikan adalah terkait dengan prosedur bedah (27\%), kesalahan pengobatan (18,3\%) dan kesehatan infeksi terkait perawatan $(12,2 \%)$ (WHO, 2017).

Laporan insiden keselamatan pasien di Indonesia berdasarkan propinsi menunjukkan bahwa dari 145 insiden yang dilaporkan terdapat 55 kasus $(37,9 \%)$ terjadi di wilayah DKI Jakarta. Sedangkan berdasarkan jenisnya didapatkan Kejadian Nyaris Cedera (KNC) sebanyak 69 kasus (47,6\%), KTD sebanyak 67 kasus $(46,2 \%)$ dan lain-lain sebanyak 9 kasus $(6,2 \%)$. Pelaporan insiden keselamatan pasien di rumah sakit belum dikembangkan secara menyeluruh oleh semua rumah sakit sehingga perhitungan kejadian yang berhubungan dengan keselamatan pasien masih sangat terbatas. Peningkatan proporsi 
budaya baik pada penerapan budaya sebelum dansesudah intervensi pada kelompok intervensi bermakna secara klinis dan statistik.

Insiden Keselamatan pasien berupa medication error dari data yang didapat, $59 \%$ responden menyatakan pernah melakukan insiden medication error berupa pemberian obat tidak sesuai dengan waktu yang diberikan, $47.7 \%$ tidak melakukan dokumentasi dengan lengkap obat yang sudah diberikan , $56.77 \%$ terjadi kesalahan penghitungan tetesan infus sehingga cairan yang masuk tidak sesuai dengan seharusnya ( terlampau cepat atau terlampau lambat), $54.5 \%$ tidak melakukan pendokumentasian cairan masuk, cairan keluar, IWL dengan benar sehingga tidak diketahui balance cairan dan diuresis pasien dengan tepat. Hal ini juga sesuai dengan data IKP tahun 2014 dimana penyebab insiden di RS X adalah komunikasi menempati urutan kedua bersama dengan komunikasi.

\section{PEMBAHASAN}

Isu keselamatan pasien melahirkan paradigma baru tentang mutu pelayanan. Mutu pelayanan yang baik saja tidak cukup berarti bagi pasien tanpa memperhatikan bagaimana derajat unsur resiko dan keselamatan yang diterima oleh pasien.
Tinggi rendahnya mutu sebanding dengan tingkat ketersediaan fasilitas pelayanan, untuk mencapai keseimbangan terbaik antara risiko dan manfaat keselamatan yang diterima oleh pasien. Sasaran Keselamatan Pasien (SKP) menjadi indikator standar dasar yang utama dalam penilaian Akreditasi Rumah Sakit versi 2012 (KARS, 2013). Ada enam sasaran keselamatan pasien yaitu Ketepatan identifikasi pasien; Peningkatan komunikasi yang efektif; Peningkatan keamanan obat yang perlu diwaspadai; Kepastian tepat- lokasi, tepatprosedur, tepat-pasien operasi; Pengurangan risiko infeksi terkait pelayanan kesehatan; dan Pengurangan risiko pasien jatuh (Permenkes Nomor 1691, 2011). World Health Organization (WHO) menyatakan keselamatan pasien merupakan masalah kesehatan masyarakat global yang serius. Kesalahan medis dapat disebabkan oleh faktor sistem dan faktor manusia.

Faktor-faktor yang berkontribusi terhadap terjadinya kesalahan menurut Reason (Hughes,2008) adalah

- Faktor Individu

Factor tingkat pertama yang memiliki dampak langsung pada kinerja pelayan kesehatan dan apakah kinerja tersebut dapat diterima atau dianggap dibawah standard. 
Karakteristik indvidu mencakup semua kualitas yang dimiliki setiap orang untuk melakukan pekerjaan seperti pengetahuan, tingkat ketrampilan, pengalaman, kecerdasan, kemampuan sensorik, pelatihan dan pendidikan, pengetahuan yang terakreditasi merupakan dasar kemampuan perawat untuk melakukan pekerjaan tetapi disamping itu factor organismik seperti kelelahan akibat melakukan pekerjaan berjam jam dapat mempengaruhi pemberi layanan dalam menampilkan kerja yang optimal disamping motivasi.

- Faktor sifat pekerjaan (the nature of work)

Fakor tingkat kedua mengacu pada sifat pekerjaan itu sendiri termasuk sejauh mana prosedur yang telah terdefinisi dengan baik dimanfaatkan, sifat alur kerja, ada atau tidaknya kerjasama tim, kompleksitas perawatan, fungsi peralatan, interupsi dan persaingan tugas, syarat fisik ataukognitif untuk melakukan pekerjaan. Ada banyak penelitian menyatakan bahwa kemahiran manusia dalam melakukan pekerjaan memainkan peranan penting.

- Factor interaksi manusia-system

Faktor di tingkat ketiga, interaksi manusia dengan system biasanya mengacu pada cara dua subsystem berinteraksi atau berkomunikasi dalam batas batas system. Apakah perangkat yang disediakan sesuai dengan pengetahuan atau kemampuan pengguna, apakah ciri ciri fisik, kognitif dan afektif kebutuhan pasien diperhitungkan dalam desain dan pengggunaan perangkat. Perangkat atau alat harus dirancang atau dipilih sedemikian rupa sehingga pengguna (baik perawat atau dokter) mengetahui status alat tersebut berfungsi dengan baik atau tidak, di beberapa unit seringkali tersedia alat yang sama dalam berbagai merek sehingga memberikan beban kognitif bagi pengguna (perawat atau dokter) dimana mereka harus menghafalkan langkah langkah penggunaan alat dari berbagai merk. Kemudahan dalam menggunakan peralatan dan kemudahan dalam mengoperasionalkan alat berpengaruh terhadap terjadinya kesalahan.

- Faktor Lingkungan Fisik

Faktor di tingkat ketiga, keselamatan dan kualitas pelayanan harus diperhitungkan dalam pembangunan fisik fasilitas (desain interior, tehnik lingkungan) standarisasi sistem fasilitas dan peralatan, kamar pasien sehingga sesuai dengan kebutuhan pasien dan pengunjung. Area lingkungan kerja dengan tingkat kebisingan tinggi dapat menurunkan fungsi pendengaran pekerja baik dalam jangka waktu panjang maupun 
pendek. Pencahayaan yang kurang memadai di lingkungan kerja juga berpotensi memacu Human error karena mengganggu fungsi penglihatan pekerja seperti mata kabur dan silau. Disamping itu temperature lingkungan yang tinggi maupun terlalu rendah dapat mempengaruhi kesehatan dan kenyamanan bekerja (Anita 2010). Seluruh gangguan kesehatan dan kenyamanan bekerja inilah yang dapat memicu Human Error karena pekerja kehilangan konsentrasi, kelelahan, dan menurunkan kinerja serta manual skill pekerja.

- Faktor Lingkungan organisasi atau social

Faktor di tingkat ketiga iklim organisasi, norma kelompok, moral yang dianut memberikan dampak terhadap terjadinya insiden.misalnya normalisasi terhadap penyimpangan pelayanan kesehatan terhadap kekurangan tenaga perawat dan kondisi kerja yang buruk bagi perawat tetapi karena perawat memiliki etos kerja yang baik, komitmen kerja yang baik sehingga hal ini dianggap biasa sampai kemudian pada batas tertentu terjadi insiden.

\section{- Faktor Management}

Faktor di tingkat ke empat, Kondisi perencanaan yang buruk, kebingungan atau ke lalaian yang terkait dengan manager atau orang orang dalam posisi pengambilan keputusan disebut kelalaian laten karena menjadi hulu. Praktek organisasi dan management seperti pengaturan jumlah tenaga (ketenagaan atau staffing), komunikasi, beban kerja, penjadwalan pasien,kemampuan personel mengakses (accessibility personnal), penyisipan teknologi baru, jaminan kualitas prosedur memiliki dampak terhadap terjadinya insiden.

Mengukur keselamatan, bagaimanapun, bukan semata-mata mengukur bahaya. Menilai keselamatan dengan apa yang telah terjadi di masa lalu, meski informatif, tidak dengan sendirinya memberi tahu Anda betapa berbahayanya saat ini atau akan berada di masa depan. Keselamatan berkaitan dengan berbagai cara di mana sistem dapat gagal berfungsi, yang tentunya jauh lebih banyak daripada mode fungsi yang dapat diterima. Beberapa kegagalan ini mungkin sudah tidak asing lagi, bahkan bisa diprediksi, namun sistem ini mungkin juga tidak berfungsi dengan cara yang tidak terduga. Keselamatan sebagian dicapai dengan waspada terhadap gangguan ini, merespons dengan cepat untuk menjaga agar tetap berjalan lancar. Dokter, perawat dan manajer keperawatan melakukan ini sepanjang waktu dalam perawatan kesehatan, 
mungkin lebih besar daripada industri lainnya. Tapi ketika mereka berhasil, atau sistem mengkompensasi dengan cara lain, tindakan ini dalam arti tidak terlihat.

Masalah keselamatan hampir selalu merupakan akibat dari kehilangan informasi atau informasi yang tersedia namun tidak ditindaklanjuti. Ini dimainkan dengan beberapa cara yang berbeda. Pertama, jika perawat tidak dalam komunikasi yang baik dengan pasien, dia mungkin tidak mendengar atau memahami signifikansi dari sesuatu yang coba coba dikatakan pasien. Hal ini dapat disebut sebagai "informasi yang hilang." Kedua, karena pasien akan menemui anggota tim perawatan lainnya pada waktu yang berbeda sepanjang hari, informasi penting tentang pasien harus dilewatkan ke anggota tim lainnya pada berbagai waktu. Jika perawat tidak dalam hubungan baik dengan anggota tim lainnya, dia mungkin akan melupakan, atau menahan, atau menyampaikan informasi dengan cara yang terburu-buru sehingga tidak benarbenar mendaftar. Sebagai alternatif, penerima informasi mungkin terburu-buru atau sibuk atau dengan cara lain tidak memperhatikan, dan perawat mungkin tidak sempat menjelaskannya. Hal ini dapat disebut sebagai "informasi yang tidak ditindaklanjuti".
Kasus salah diagnosa, perlakuan salah, pemberian obat yang salah hampir selalu merupakan akibat dari masalah komunikasi tersebut. Perawat tidak mendengar atau menangkap sesuatu yang ingin dikatakan pasien, atau tidak dengan jelas menyampaikan informasi ini ke dokter atau orang lain yang akan berurusan dengan pasien, atau tidak mendengar dengan jelas apa yang dilakukan dokter atau anggota lain dari tim tersebut mencoba mengatakan kepadanya. Sangat menggoda untuk kemudian menyalahkan salah satu anggota tim ketika keadaan berjalan buruk dan pasien meninggal dunia, alih-alih menyadari bahwa setiap anggota tim, terutama perawat, berada dalam peran koordinasi yang sulit di mana hubungan baik sangat penting bagi penyebaran dan pemanfaatan informasi yang relevan dari pasien.

\section{PENUTUP}

\section{KESIMPULAN}

Isu keselamatan pasien melahirkan paradigma baru tentang mutu pelayanan. Mutu pelayanan yang baik saja tidak cukup berarti bagi pasien tanpa memperhatikan bagaimana derajat unsur resiko dan keselamatan yang diterima oleh pasien. hasil Insiden keselamatan pasien yang merugikan adalah terkait dengan prosedur bedah (27\%), 
kesalahan pengobatan (18,3\%) dan kesehatan infeksi terkait perawatan $(12,2 \%)$ (WHO, 2017). Keselamatan pasien terutama berkaitan dengan penghindaran, pencegahan dan perbaikan hasil buruk atau injuri yang berasal dari perawatan kesehatan itu sendiri. Ini harus membahas kejadian yang mencakup rangkaian "kesalahan" dan "penyimpangan" terhadap kecelakaan.

\section{SARAN}

Isu keselamatan pasien sudah banyak beredar dikalangan masyarakat, hal itu yang membuat para perawat dan tenaga medis lainnya harus mampu meningkatkan pemahaman mengenai keselamatan pasien. Agar parah mahisiswa dan juga perawat dan para medis lainnya dapat meningkatkan pemahaman tentang keselamatan pasien, perawat harus memiliki pengetahuan yang luas terkait isu keselamatan pasien.

\section{DAFTAR PUSTAKA}

Bawafaa, E.., Wong, CA..,\& Laschinger,H.2015. The Influence Of Resonant Leadership on the Structural Empowerment and job Satisfaction of registered nurses. Journal of Research In Nursing. Vol: 20(7).610-622.

Budi, S.C. Sunartini. Lazuardi, L. Tetra, F.S. (2019). Tren Insiden Berdasarkan Sasaran
Keselamatan Pasien Incident Trends Based On Patient Safety Targets. Jurnal Manajemen Informasi Kesehatan Indonesia. ISSN: 2337-6007. 7(2). 141-146.

Dewi, M. (2012). Pengaruh Pelatihan Timbang Terima Pasien Terhadap Penerapan Keselamatan Pasien Oleh Perawat Pelaksana di RSUD Raden. Jurnal Health \& Sport. 5(3). 646-655.

Friyanti, E.S. (2015). Analisis Kualitas dan Kuantitas Tenaga Keperawatan Terhadap Persepsi Insiden Keselamatan Pasien. 2(1). 43-52.

Hakim,Lukman, Widodo J.Pudjirahardjo.2014. Optimalisasi Proses Koordinasi Program Keselamatan Pasien (Patient Safety) Di Rumah Sakit X Surabaya. Jurnal Administrasi Kesehatan Indonesia. Vol: 2(3).198-208.

Simamora, R. H., \& Nurmaini, C. T. S. (2019). Knowledge of Nurses about Prevention of Patient Fall Risk in Inpatient Room of Private Hospital in Medan. Indian Journal of Public Health Research \& Development, 10(10), 759-763.

Sumami.2017. Analisis Implementasi Patient Safety terkait Peningkatan Mutu Pelayanan Kesehatan di Rumah Sakit. 
Jurnal Ners dan Kebidanan Indonesia. 5(2).

91-99.

Triwibowo,Cecep, Sulhah Yuliawati, Nur Amri Husna.2016. Handover Sebagai Upaya Peningkatan Keselamatan Pasien (patient safety) di Rumah Sakit. Jurnal Keperawatan Soedirman. Vol: 11(2).76-80.

Tutiany. Lindawati. Krisanti, P. (2017). Manajemen Keselamatan Pasien. Jakarta: EGC.

Ulumiyah, N.A. (2018). MENINGKATKAN MUTU PELAYANAN KESEHATAN DENGAN PENERAPAN UPAYA KESELAMATAN PASIEN DI PUSKESMAS. Jurnal Administrasi

Kesehatan Indonesia. 6(2). 149-155.

Utarini,Adi, Hanevi Djasri.2012. Keselamatan Pasien dan Mutu Pelayanan Kesehatan: Menuju kemana. Jurnal Manajemen Pelayanan Kesehatan. Vol: 15(4).159-160. 